\title{
Prevalence of Non-motor Symptoms in Parkinson's Disease: A Study from South India
}

\author{
Parkinson Hastalı̆̆ında Non-motor Semptomların Prevalansı: Güney Hindistan'dan \\ Bir Çalışma
}

(1) Jay Ray Chaudhuri1, (1) Kandadai Rukmini Mridula2, () Vcs Srinivasarao Bandaru1

1 Yashoda Hospital, Clinic of Neurology, Hyderabad, India

2Nizam's Institute of Medical Sciences, Department of Neurology, Hyderabad, India

\begin{abstract}
Objective: Non-motor symptoms (NMS) play a vital role in managing Parkinson's disease (PD) and have become the leading cause of deterioration of quality of life with the progression of the disease. The aim of the present study was to investigate the prevalence of NMS in PD with disease duration.

Materials and Methods: We selected 75 patients with PD prospectively and all patients were diagnosed according to the United Kingdom PD Brain Bank criteria. All patients were trichotomized based on disease duration ( $\leq 4$ years, $5-8$ years and $\geq 9$ years). The NMS screening questionnaire comprising 30 items was completed by all patients.

Results: Out of 75 patients, men constituted $82.6 \%$, the mean age was $59.2 \pm 1.51$ (range, 45-69) years. The overall prevalence of NMS was $100 \%$. Among the patients with a disease duration of $\leq 4$ years, $5-8$ years, and $\geq 9$ years, gastrointestinal symptoms were observed in $38 \%$, 48\%, and $86.2 \%$; cardiovascular dysfunction in $47.6 \%, 44 \%$, and $82.7 \%$; urinary problems in $38 \%, 40 \%$, and $72.4 \%$; poor sexual performance in $42.8 \%$, $40 \%$, and $79.3 \%$; sleep disturbance in $38 \%, 36 \%$, and $75.8 \%$; anxiety in $33.3 \%, 40 \%$, and $79.3 \%$; hallucinations in $33.3 \%, 36 \%$, and $72.4 \%$; and cognition problems in $38 \%$, $32 \%$, and $72.4 \%$, respectively. Significantly higher prevalences of gastrointestinal symptoms $(\mathrm{p}=0.006)$, cardiovascular dysfunctions $(\mathrm{p}=0.007)$, urinary problems $(\mathrm{p}=0.03)$, poor sexual performance $(\mathrm{p}=0.007)$, sleep disturbances $(\mathrm{p}=0.007)$, anxiety $(\mathrm{p}=0.007)$, hallucinations $(\mathrm{p}=0.03)$, and cognitive problems $(\mathrm{p}=0.007)$ were noted in patients with $\geq 9$ years disease duration.
\end{abstract}

Conclusion: Our study established that $100 \%$ of patients with PD had at least one NMS and there was a higher prevalence of NMS among those with disease duration more than 9 years.

Keywords: Non-motor symptoms (NMS), Parkinson's disease, disease duration, gastrointestinal symptoms, cardiovascular dysfunctions

\section{$\ddot{O} \mathbf{z}$}

Amaç: Non-motor semptomlar (NMS), Parkinson hastalığının (PH) yönetiminde hayati bir rol oynar ve hastalığın ilerlemesi ile yaşam kalitesinin bozulmasının önde gelen nedeni haline gelmiştir. Bu çalışma, hastalık süresine göre PH'de NMS prevalansını araştırmaktır.

Gereç ve Yöntem: Yetmiş beş PH tanısı olan hasta bu prospektif çalışmaya dahil edildi. Bütün hastalara Birleşik Krallık PD Beyin Bankası kriterlerine göre tanı kondu. Hastalar hastalık süresine göre 3 gruba ayrıldı ( $\leq 4$ yıl, $5-8$ yıl ve $\geq 9$ yıl). Otuz sorudan oluşan NMS tarama anketi tüm hastalar tarafindan dolduruldu. Bulgular: Yetmiş beş hastanın \%82,6'sını erkekler oluşturmaktaydı ve yaş ortalaması 59,2 $\pm 1,51$ yıl idi (45-69 yaş). NMS'nin genel prevalansı \%100 idi. Hastalık süresi 4 yıl, 5-8 yıl ve $\geq 9$ yıl olan hastalarda gastrointestinal semptomların prevalansı sırasıyla $\% 38$, \%48 ve $\% 86,2$, kardiyovasküler hastalıkların prevalansı sirasiyla $\% 47,6, \% 44$ ve $\% 82,7$, idrar sorunlarının prevalansı sirasılla $\% 38, \% 40$ ve $\% 72,4$, zayıf cinsel performansın prevalansı sirasıyla $\% 42,8, \% 40$ ve $\% 79,3$, uyku bozukluklarının prevalansı sirasıyla $\% 38, \% 36$ ve $\% 75,8$, anksiyetenin prevalansı sirasıly $\% 33,3, \% 40$ ve $\% 79,3$, halüsinasyonların prevalansı sırasıyla $\% 33,3, \% 36$ ve $\% 72,4$, bilişsel problemlerin prevalansı sırasıyla $\% 38, \% 32$ ve $\% 72,4$ idi. Hastalık süresi $\geq 9$ yıl olan hastalarda; sindirim sistemi semptomları $(p=0,006)$, kardiyovasküler bozukluklar $(p=0,007)$, idrar sorunları $(p=0,03)$, kötü cinsel performans $(p=0,007)$, uyku bozuklukları ( $p=0,007)$, anksiyete $(\mathrm{p}=0,007)$, halüsinasyonlar $(\mathrm{p}=0,03)$ ve bilişsel sorunlar $(\mathrm{p}=0,007)$ anlamlı derecede daha yüksek prevalansta görüldü.

Sonuç: Çalışmamız, PH tanılı hastaların \%100'ünün en az bir NMS'ye sahip olduğunu ve 9 yıldan fazla hastalık süresi olanlarda daha yüksek NMS prevalansı olduğunu ortaya koymuştur.

Anahtar Kelimeler: Non-motor semptomlar, Parkinson hastalığ ${ }_{1}$, hastalık süresi, gastrointestinal semptomlar, kardiyovasküler disfonksiyonlar

Address for Correspondence/Yazışma Adresi: Vcs Srinivasarao Bandaru PhD, Yashoda Hospital, Clinic of Neurology, Hyderabad, India Phone: 914027776666 E-mail: rsbhandaru@gmail.com ORCID: orcid.org/0000-0001-6783-5289

Received/Geliş Tarihi: 12.11.2019 Accepted/Kabul Tarihi: 07.01.2021

${ }^{\circ}$ Copyright 2021 by Turkish Neurological Society

Turkish Journal of Neurology published by Galenos Publishing House. 


\section{Introduction}

Parkinson's disease (PD) is the second most common neurodegenerative disorder, it affects all age groups and both sexes (1). Worldwide, the crude prevalence is around 160 per 100,000 (2), and in India 6-53 per 100,000 (3). PD is characterized by motor symptoms such as rigidity, postural instability, resting tremor, bradykinesia, and non-motor symptoms (NMS) such as cognitive impairment, cardiovascular dysfunction, sleep disturbances, psychiatric, urinary problems, and gastrointestinal symptoms (4). Existing studies have marked the importance of NMS as a major cause of disability and poor quality of life in patients with PD $(4,5,6)$. The present study investigated the prevalence of NMS in patients with PD with varying duration of disease. Limited data are available from South India on this topic.

\section{Materials and Methods}

We prospectively recruited 75 patients with PD from the Department of Neurology Yashoda Hospital, Hyderabad. Yashoda Hospital is a tertiary care center of South India. The study period was between June 2014 and May 2017.

The patients were diagnosed as having PD according to the United Kingdom PD Brain Bank criteria (5). Patients with PD who were wheelchair or bed-bound, had dementia or severe psychiatric disturbances, Hoehn and Yahr stage 5, and atypical and secondary parkinsonism were excluded from the study. Demographic information and clinical findings were collected through face-to-face interviews. Motor symptoms of PD were evaluated with the Unified PD Rating Scale part-III (UPDRS-III).

Detailed neurologic examinations were performed in all patients by two movement disorder specialists and one senior neurologist. Medical history was collected (present and past) from medical records and reviewed by a trained neurology resident for all patients. Non-pharmacologic (e.g. physical, occupational, and speech therapies) and pharmacologic therapies (doses of various dopaminergic drugs) were studied in all patients. Assessment of motor deficits was performed in both "off" (dopaminergic drugs stopped for 12 hours) and "on" (maximum improvement with medication) states using UPDRS-III, which assesses motor functions. We trichotomized the patients based on disease duration, $\leq 4$ years, $5-8$ years, and $\geq 9$ years. This study was approved by the Institutional Ethics Committee (file no: RP-18/2011) and informed consent was obtained from the patients.

\section{Non-motor Symptoms Assessment}

NMS Quest is a self-completed 30-item comprehensive questionnaire with "yes" and "no" type answers. All items identify the presence or absence of symptoms (5). The 30 questions were categorized into 9 domains: Urinary, sexual, gastrointestinal, cognition (apathy/attention/memory), anxiety/depression, cardiovascular, hallucinations/delusions, and sleep. Seven questions (dribbling of saliva, reduced taste or smell, dysphagia, nausea, constipation, bowel incontinence and incomplete bowel emptying) were part of the gastrointestinal domain. The cardiovascular domain had two questions (feeling light-headed and falling or syncope), the urinary domain assessed urgency and frequency of micturition. The memory domain included memory problems, loss of interest and difficulty in concentration, and the anxiety/depression domain had single questions in each (feeling sad and feeling anxious/frightened). The sleep domain identified five symptoms [insomnia, increased drowsiness with difficulty in staying awake, vivid dreams, talking or moving in sleep or rapid eye movement (REM) sleep behavioral disorders, unpleasant sensations in the legs or restless leg syndrome]. Difficulty in performing sex or loss of interest in sex was classified into the sexual domain, and the presence of hallucinations and delusions was in the hallucinations/depression domain.

\section{Cognition Assessment}

Cognition in all patients with PD was assessed using the Montreal Cognitive Assessment (MoCA) scale. The time for the administration of MoCA was approximately 10 minutes. The total possible score is 30 points; a score of $\geq 26$ is considered normal $(7,8)$.

\section{Statistical Analysis}

Statistical analysis was performed using the Statistical Package for the Social sciences statistical package (SPSS Ver. 12.0, SPSS Inc., Chicago IL, USA). Continuous variables are presented in titer of mean and \pm standard deviation. The chi-square test was used to study the difference between the three groups. All tests were twosided and $\mathrm{p}<0.05$ was considered statistically significant.

\section{Results}

In the current study, there were $62(82.6 \%)$ men, the mean age was $59.2 \pm 1.51$ (range, 45-69), and the duration of PD ranged from 1 to 14 years. The mean UPDRS-III score in the "off" state was $41.3 \pm 9.43$, the mean UPDRS-III score in the "on" state was $11.2 \pm 6.98$, motor fluctuations were seen in $13(17.3 \%)$ patients, dyskinesia in $24(32 \%)$, and gait freezing in 20 (26.6\%) (Table 1).

Among the NMS domains, gastrointestinal symptoms $(\mathrm{p}=0.006)$, cardiovascular dysfunction $(\mathrm{p}=0.007)$, urinary problems $(\mathrm{p}=0.03)$, sexual dysfunction $(\mathrm{p}=0.007)$, sleep disturbances $(\mathrm{p}=0.007)$, anxiety/depression $(\mathrm{p}=0.007)$ hallucinations/delusions $(\mathrm{p}=0.03)$, and cognitive problems $(\mathrm{p}=0.007)$ were significantly associated with $\geq 9$ years' disease duration (Table 2 ).

\section{Discussion}

In our study we established that at least one NMS was present in all patients with PD $(100 \%)$, our findings are supported by other authors: Krishnan et al. (9) 100\%, Liu et al. (10) $98 \%$, Li et al. (11) $100 \%$, Barone et al. (12) $98.6 \%$, Zhang et al. (6) $99.4 \%$, Ravan et al. (13) 98.4\%, and Mridula et al. (5) $98 \%$.

\section{Gastrointestinal Symptoms}

Studies have established that gastrointestinal symptoms are higher in Asian PD patients (14). We also found a significantly higher prevalence of gastrointestinal symptoms with an overall prevalence of $60 \%$. Most studies noted higher than $50 \%$ prevalence $(5,10,14)$, but some have shown a lower prevalence $(12,15)$. Onethird of our patients had symptoms in early disease, and it increased to $85 \%$ when the disease duration was more than nine years.

Gastrointestinal system involvement may start years before the onset of motor symptoms and the presence of constipation is common in PD. The vagus nerve is the main supply of parasympathetic innervation to the gastrointestinal system $(16,17)$. Abnormalities of the cholinergic innervation lead to impaired gut motility. There may be an added component of dystonia involving 
Table 1. Baseline characteristics

\begin{tabular}{ll} 
Parameters & $(\mathrm{n}=75)$ \\
Men & $62(82.6 \%)$ \\
Mean age & $59.2 \pm 1.51$ \\
Age range & $45-69$ \\
Any non-motor symptoms & $75(100 \%)$ \\
Disease duration & $1-14$ \\
Mean UPDRS-III score in "off" state & $41.3 \pm 9.43$ \\
Mean UPDRS-III score in "on" state & $11.2 \pm 6.98$ \\
Motor fluctuation & $13(17.3 \%)$ \\
Dyskinesia & $24(32 \%)$ \\
Gait freezing & $20(26.6 \%)$ \\
Family history of PD & $2(2.6 \%)$ \\
Modified Hoehn \& Yahr stage $\leq 2$ & $42(56 \%)$ \\
Modified Hoehn \& Yahr stage 2-3 & $23(30.6 \%)$ \\
Modified Hoehn \& Yahr stage 4 & $10(13.3 \%)$ \\
Tremors as the initial presenting symptom & $45(60 \%)$ \\
Bradykinesia/rigidity as the initial presenting & $30(40 \%)$ \\
symptom & \\
Medications & $31.27 \pm 72.14$ \\
Number of patients on levodopa & \\
Number of patients on dopamine agonists & $12(16 \%)$ \\
Number of patients on amantadine & $32(42.6 \%)$ \\
Number of patients on anticholinergics & $17(22.6 \%)$ \\
Antidepressant & $20(26.6 \%)$ \\
Monoamine oxidase B inhibitors & $13(17.3 \%)$ \\
Medications dosage & \\
Mean levodopa dose (mg/day) & \\
Total LED (mg/day) & \\
Dopamine agonist-LED (mg/day) & \\
\hline disease, Levodopa equivalent daily dose & \\
\hline
\end{tabular}

the striated external anal sphincter. A third contribution may occur from the attrition of dopamine-containing neurons in the enteric plexus innervating the colon (17). Other supporting evidence is in the presence of infections such as Helicobacter pylori, which is strongly associated with PD and may lead to chronic inflammation in the gut (18). Other gastrointestinal symptoms apart from constipation, include sialorrhea, dysphagia, nausea, and defecatory dysfunction. Our study also adds to the evidence that gastrointestinal symptoms progress with disease duration. There seems to be no response to levodopa therapy and gastrointestinal symptoms are difficult to treat.

We did not quantify further, but tests such as detailed esophagography, electromyogram of the anal sphincter, intestinal motility and transit studies, and defecating proctography can be studied to find more effective and specific therapies for gastrointestinal symptoms.

\section{Cardiovascular Dysfunctions}

The association of the cardiovascular system in PD is of high significance because many patients have orthostatic hypotension and the prevalence ranges from $30-58 \%$ (19). In our study, orthostatic symptoms were the most prevalent NMS even in early disease with increasing prevalence as the disease duration increased; $83 \%$ among patients with longer disease duration ( $\geq 9$ years) had symptoms. Similar prevalence has been reported in other studies (5); however, few studies have shown less than $50 \%(15,20)$.

The pathophysiology of autonomic dysfunction in patients with PD is due to peripheral sympathetic denervation of the heart, as demonstrated with 123I-metaiodobenzylguanidine-based single-photon emission computed tomography. This is in contract to multiple system atrophy where there is a central pathology (21). Unfortunately, orthostatic hypotension may be associated with supine hypertension (22). In normal individuals, there is a diurnal trend in blood pressure (BP) with higher values in the daytime and lower in sleep. Tsukamoto et al. (23) performed 24 hours ambulatory BP monitoring in patients with PD and showed a defect in the normal diurnal variation with increased nocturnal BP, similar to patients with essential hypertension. This leads to double jeopardy with orthostatic hypotension predisposing to falls and supine hypertension leading to end-organ damage with increased risk of cerebrovascular and cardiovascular events (24).

There is a variation of BP in the "off" and "on" stage in patients with PD (25), with higher BP in the "off” state. Although partially explained by the effect of dopaminergic drugs, it is also contributed

Table 2. Comparison of NMS with disease duration

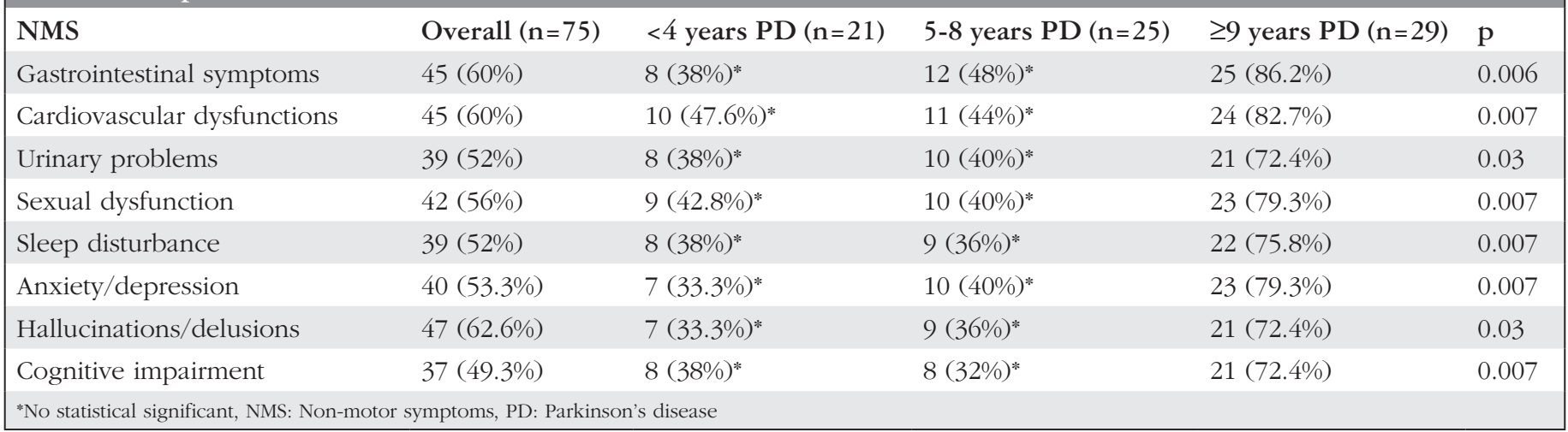


by the disease itself. It is seen that patients with PD who have onoff-type motor fluctuations also demonstrate higher resting heart rate, increased orthostatic hypotension, and decreased responses during the Valsalva maneuver and the cold pressor test during the "off" state when compared with healthy control subjects (26).

\section{Urinary Symptoms}

Urinary symptoms are a major problem in patients with PD. Nocturia is common, causing impairment in sleep. In this study, the overall prevalence of urinary symptoms was $50.6 \%$ with $72.4 \%$ when disease duration was greater than 9 years. This falls in the range of prevalence rates shown in previous studies; Liu et al. (10) $56 \%$, Mridula et al. (5) 86.7\%, Martinez-Martin et al. (20) 59\%, Vongvaivanich et al. (15) 54.6\%, and Azmin et al. (14) $32.7 \%$.

A highly complex mechanism underlies urinary dysfunction in PD. It is influenced by dopaminergic neurons both peripherally and in the central nervous system. The use of antiparkinsonian medication, especially anticholinergics, may further cause urinary dysfunction (27). In a single-photon emission computed tomography imaging-based study, Winge et al. (28) established an association of the severity of urinary problems with the relative degeneration of neurons in the caudate nucleus.

\section{Sexual Dysfunction}

Sexuality is an important part of a healthy life (29). Several reports have found sexual dysfunction to be associated with PD (30) and the prevalence ranges from $22 \%$ to $68.4 \%$ (30). In our study, we noted an overall prevalence of $56 \%$ and $79.3 \%$ in patients with $\geq 9$ years of disease duration. Other studies have shown slightly lower prevalences of $28.3 \%$ (5) and $33 \%$ (20). Studies have established an association of erectile dysfunction and low desire in both sexes of patients with PD with disease and treatment (31). On the other hand, drugs, especially dopamine agonists, as well as deep brain stimulation of bilateral subthalamic nuclei, can result in impulse control disorders and hypersexuality (5). Sexual dysfunction can trigger delusions of infidelity and behavioral issues causing severe caregiver stress.

\section{Sleep Disturbance}

Sleep disturbances were reported by $39(52 \%)$ patients in our cohort. Among those with disease duration $\geq 9$ years, the prevalence was $75.8 \%$. Similar findings were noted by others $(5,12,14)$.

Sleep is affected by various reasons in PD. Other motor symptoms such as increased rigidity, NMS such as nocturia, depression, and hallucinations can impair sleep. PD in itself leads to degeneration of central regulators of sleep in the brainstem, thalamus, and cortex. Sleep fragmentation is most frequently seen but insomnia and excessive daytime somnolence (with added contribution from medication) are also common, and REM sleep behavioral disorder can predate the motor symptoms by a decade (32). Although sleep dysfunction is not purely due to dopaminergic dysfunction, several studies have suggested that dopaminergic drugs, as well as deep brain stimulation, could improve sleep dysfunction in PD (33).

\section{Depression/Anxiety}

Depression or anxiety can be secondary to any disease, but in PD, it may be an integral part of the disease. Existing studies have shown the prevalence of depression, psychosis, and anxiety to range from $16 \%$ to $70 \%(5,10,12,14)$. In our study, we found an overall prevalence of $53.3 \%$ with the maximum prevalence in those with $\geq 9$ years' disease duration $(79.3 \%)$.

Neurodegeneration plays a major role in causing depression in patients with PD. The brain stem structures that degenerate include the locus coeruleus and raphe nucleus, along with the substantia nigra, as has been demonstrated by pathologic studies performed by Braak et al. (34). Involvement of noradrenergic and serotonergic neurons underlie the pathophysiology of depression in PD. This was evidenced by a positron emission tomography (PET) study, which showed lower dopamine and noradrenaline transporter levels in the limbic system, as well as the locus coeruleus (35). Similarly reduced serotonergic 1A receptor availability in orbitofrontal and limbic regions has been demonstrated using ${ }^{18} \mathrm{~F}$-fluorodeoxyglucose PET (36). Ishihara and Brayne (37) established a two to three-fold increase in the prevalence of depression in patients with PD in comparison with healthy people. Depression can occur before motor symptoms and may be present for 4-6 years before PD is diagnosed (37).

\section{Hallucinations/Delusions}

Hallucinations and delusions are more common in older patients and those who have a bradykinetic rigid variant. A much higher prevalence was noted in the present study, $49 \%$ overall. Others studies have shown varying prevalences, lower $15 \%$ by Mridula et al. (5) $17 \%$ by Martinez-Martin et al. (20), Vongvaivanich et al. (15) $17.3 \%$, whereas Molho and Factor (38) identified it in $30 \%$ and Amar et al. (39) reported a similar prevalence of $45 \%$. Generally, hallucinations occur later in the PD disease course and $72.4 \%$ of our patients with $\geq 9$ years of duration of disease had hallucinations and delusions.

Dopaminergic drugs, amantadine and anticholinergics, when used for a long time, can induce psychosis in patients with PD. This is worsened with cognitive impairment. An alternative hypothesis suggests a direct correlation with the disease itself. The "continuum hypothesis" suggests that REM sleep behavioral disorder associated with vivid dreams convert into medicationinduced hallucinations and delusions and ends in delirium.

\section{Cognition}

Cognitive impairment, previously thought to occur only in late disease, is now recognized to occur from the early stages of the disease. In our study, we found $33 \%$ with disease duration $\leq 4$ years had cognitive impairment compared with $72.4 \%$ of patients with disease of $\geq 9$ years' duration; our findings are supported by others $(5,16,22)$.

Dopamine agonists and levodopa may improve cognition, as seen in better performances in the "on" state compared with the "off" state, and may act by improving corticostriatal outflow (40). However, higher doses and anticholinergics can impair cognition and behavior.

\section{Study Limitations}

The strength of the study is that all patients were evaluated by a single movement disorder specialist, excluding inter-rater bias and the study population covered the disease duration from early to advanced disease. We have few limitations. The sample size was small and we used only a simple questionnaire in a cross-sectional study. We could not assess the impact of medications on NMS. 


\section{Conclusion}

In our study, all patients $(100 \%)$ had at least one NMS, the most prevalently affected domains were gastrointestinal and cardiovascular, followed by sexual dysfunction, cognition, and anxiety/depression. NMS frequency increased with disease duration ( $\geq 9$ years). Treatment options are limited, though increased dopaminergic medications or deep brain stimulation may help.

\section{Acknowledgements}

We thank Dr. Surender Rao G, MD Yashoda group of hospitals and Dr. Lingaih A, DMS, for their support, which made it possible to conduct this study at Yashoda Hospital, Hyderabad, Telangana, India.

\section{Ethics}

Ethics Committee Approval: This prospective Parkinson disease registry and the registry based study was approved by Institutional Ethics Committee (Yashoda Academy of Medical Education and Research) file no: RP-18/2011.

Informed Consent: Informed consent was taken from all participating patients.

Peer-review: Externally and internally peer-reviewed.

\section{Authorship Contributions}

Concept: K.R.M., V.S.B., Design: J.R.C., K.R.M., Data Collection or Processing: J.R.C., K.R.M., Analysis or Interpretation: K.R.M., V.S.B., Writing: J.R.C., K.R.M.

Conflict of Interest: The authors have not declared any conflict of interest related to this article.

Financial Disclosure: The authors declared that this study received no financial support.

\section{References}

1. De Lau LM, Breteler MM. Epidemiology of Parkinson's disease. Lancet Neurol 2006;5:525-535.

2. Gupta BM, Bala A. Parkinson's disease in India: An analysis of publications output during 2002-2011. Int J Nutr Pharmacol Neurol Dis 2013;3:254262.

3. Gourie-Devi M. Epidemiology of neurological disorders in India: review of background, prevalence and incidence of epilepsy, stroke, Parkinson's disease and tremors. Neurol India 2014;62:588-598.

4. Chaudhuri, KR, Schapira, AH. Non-motor symptoms of Parkinson's disease: dopaminergic pathophysiology and treatment. Lancet Neurol 2009;8:464-474

5. Mridula KR, Borgohain R, Jabeen SA, et al. Comparison of frequencies of non motor symptoms in Indian Parkinson's disease patients on medical management versus deep brain stimulation: A case-control study. Iran J Neurol 2015;14:86-93.

6. Zhang H, Gu Z, An J, Wang C, Chan P. Non-motor symptoms in treated and untreated Chinese patients with early Parkinson's disease. Tohoku J Exp Med 2014;232:129-136

7. Nasreddine ZS, Phillips NA, Bedirian V, et al. The montreal cognitive assessment, MoCA: A brief screening tool for mild cognitive impairment. J Am Geriatr Soc 2005;53:695-699.

8. Zadikoff C, Fox SH, Tang-Wai DF, et al. A comparison of the mini mental state exam to the Montreal cognitive assessment in identifying cognitive deficits in Parkinson's disease. Mov Disord 2008;23:297-299.

9. Krishnan S, Sarma G, Sarma S, Kishore A. Do nonmotor symptoms in Parkinson's disease differ from normal aging? Mov Disord 2011;26:21102113.

10. Liu WM, Lin RJ, Yu RL, et al. The impact of nonmotor symptoms on quality of life in patients with Parkinson's disease in Taiwan. Neuropsychiatr Dis and Treat 2015;11:2865-2873.
11. Li H, Zhang M, Chen L, et al. Nonmotor symptoms are independently associated with impaired health-related quality of life in Chinese patients with Parkinson's disease. Mov Disord 2010;25:2740-2746.

12. Barone P, Antonini A, Colosimo C, et al. PRIAMO study group. The PRIAMO study: A multicenter assessment of nonmotor symptoms and their impact on quality of life in Parkinson's disease. Mov Disord 2009;24:16411649

13. Ravan A, Ahmad FM, Chabria S, Gadhari M, Sankhla CS. Non-motor symptoms in an Indian cohort of Parkinson's disease patients and correlation of progression of non-motor symptoms with motor worsening. Neurol India 2015;63:166-174.

14. Azmin S, Khairul Anuar AM, HJ Tan, et al. Nonmotor symptoms in a malaysian Parkinson's disease population. Parkinsons Dis 2014;2014:472157.

15. Vongvaivanich K, Nidhinandana S, Udommongkol C, et al. Nonmotor symptoms in Thai patients with Parkinson's disease studied at Phramongkutklao Hospital. J Med Assoc Thai 2014;97(Suppl 2):S159-S167.

16. Tredici KD, Rub U, De Vos RA, Bohl JR, Braak H. Where does Parkinson disease pathology begin in the brain? J Neuropathol Exp Neurol 2002;61:413-426.

17. Mathers SE, Kempster PA, Swash M, Lees AJ. Constipation and paradoxical puborectalis contraction in anismus and Parkinson's disease: a dystonic phenomenon? J Neurol Neurosurg Psychiatry 1988;51:1503-1507.

18. Mridula KR, Borgohain R, Chandrasekhar Reddy V, Bandaru VCS, Suryaprabha T. Association of Helicobacter pylori with Parkinson's disease. J Clin Neurol 2017;13:181-186.

19. Goldstein DS. Orthostatic hypotension as an early finding in Parkinson's disease. Clin Auton Res 2006;16:46-54.

20. Martinez-Martin P, Schapira AH, Stocchi F, et al. Prevalence of nonmotor symptoms in Parkinson's disease in an international setting; study using nonmotor symptoms questionnaire in 545 patients. Mov Disord 2007;22:1623-1629.

21. Braune S, Reinhardt M, Schnitzer R, Riedel A, Lucking CH. Cardiac uptake of [123I]MIBG separates Parkinson's disease from multiple system atrophy. Neurology 1999;53:1020-1025.

22. Pathak A, Senard JM. Blood pressure disorders during Parkinson's disease: epidemiology, pathophysiology and management. Expert Rev Neurother 2006;6:1173-1180

23. Tsukamoto T, Kitano Y, Kuno S. Blood pressure fluctuation and hypertension in patients with Parkinson's disease. Brain Behav 2013;3:710-714.

24. McGrath BP. Ambulatory blood pressure monitoring. Med J Aust 2002;176:588-592.

25. Pursiainena V, Korpelainena JT, Haapaniemia TH, Sotaniemia KA, Myllyla VV. Blood pressure and heart rate in Parkinsonian patients with and without wearing-off. Eur J Neurol 2007;14:373-378.

26. Goetz CG, Lutge W, Tanner CM. Autonomic dysfunction in patients with Parkinson's disease. Neurology 1986;36:73-75.

27. Uchiyama T, Sakakibara R, Hattori T, Yamanishi T. Short-term effect of a single levodopa dose on micturition disturbance in Parkinson's disease patients with the wearing-off phenomenon. Mov Disord 2003;18:573-578.

28. Winge K, Friberg L, Werdelin L, Nielsen KK, Stimpel H. Relationship between nigrostriatal dopaminergic degeneration,urinary symptoms, and bladder control in Parkinson's disease. Eur J Neurol 2005;12;842-850.

29. World Association for Sexual Health. Sexual health for the millennium A Declaration and technical document. Avaialable from: http://www. europeansexology.com/files/WAS_2008.pdf. Last Accessed Dated: 20.10.2018.

30. Brown RG, Jahanshahi M, Quinn N, Marsden CD. Sexual function in patients with Parkinson's disease and their partners. J Neurol Neurosurg Psychiatry 1990;53:480-486.

31. Bronner G, Royter V, Korczyn AD, Giladi N. Sexual dysfunction in Parkinson's disease. J Sex Marital Therapy 2004;30:95-105.

32. Chaudhuri KR, Healy DG, Schapira AH. Non-motor symptoms of Parkinson's disease: Diagnosis and management. Lancet Neurol 2006;5:235 245.

33. Eggert K, Schrader C, Hahn M, et al. Continuous jejuna levodopa infusion in patients with advanced parkinson disease: practical aspects and outcome of motor and nonmotor complications. Clin Neuropharmacol 2008;31:151166. 
34. Braak H, Del Tredici K, Rüb U, et al. Staging of brain pathology related to sporadic Parkinson's disease. Neurobiol Aging 2003;24:197-211.

35. Remy P, Doder M, Lees A, Turjanski N, Brooks D. Depression in Parkinson's disease: Loss of dopamine and noradrenaline innervation in the limbic system. Brain 2005;128:1314-1322.

36. Ballanger $\mathrm{B}$, Klinger $\mathrm{H}$, Eche $\mathrm{J}$, et al. Role of serotonergic $1 \mathrm{~A}$ receptor dysfunction in depression associated with Parkinson's disease. Mov Disord 2012;27:84-89.

37. Ishihara L, Brayne C. A systematic review of depression and mental illness preceding Parkinson's disease. Acta Neurol Scand 2006;113:211-220.
38. Molho ES, Factor SA. Parkinson's disease: The treatment of drug induced hallucinations and psychosis. Curr Neurol Neurosci Rep 2001;1:320-328.

39. Amar BR, Yadav R, Reddy YCJ, Pal PK. A clinical profi le of patients with Parkinson's disease and psychosis. Ann Indian Acad Neurol 2014;17:187192.

40. Cools R, Baker RA, Sahakian BJ, Robbins TW. Enhanced or impaired cognitive function in Parkinson's disease as a function of dopaminergic medication and task demands. Cereb Cortex 2001;11:1136-1143. 